Article

\title{
A Study of Temperature Effect on the Xanthate's Performance during Chalcopyrite Flotation
}

\author{
Dongbo An $@$ and Jinhong Zhang * \\ Department of Mining and Geological Engineering, The University of Arizona, Tucson, AZ 85721, USA; \\ dongboan@email.arizona.edu \\ * Correspondence: jhzhang@email.arizona.edu; Tel.: +1-520-626-9656
}

Received: 13 April 2020; Accepted: 8 May 2020; Published: 10 May 2020

\begin{abstract}
A multi-scale investigation was conducted to study the surface properties of xanthate-absorbed chalcopyrite at elevated temperature to understand the temperature effect on the xanthate's performance during chalcopyrite flotation. Firstly, a macro-scale study was initiated to investigate the temperature effect on the hydrophobicity of mineral surface by means of contact angle measurement, Hallimond tube microflotation and lab flotation tests; secondly, a micro-scale study was conducted to clarify the temperature effect on the adsorption of chemicals on mineral surface employing an atomic force microscope (AFM) and Fourier transform infrared spectroscopy-attenuated total reflectance (FTIR-ATR). In the experiments, pure chalcopyrite samples were used for contact angle measurement, Hallimond tube microflotation, AFM and FTIR; and copper ore samples $(1.51 \%$ $\mathrm{Cu}, 5.88 \% \mathrm{Fe} 0.029 \% \mathrm{Mo}, 5.23 \% \mathrm{~S}$ in weight percentage) were used for lab flotation tests. FTIR spectra and AFM images showed that, when potassium amyl xanthate (PAX) was used as the collector in this study, oily dixanthogen was the main hydrophobic species on the chalcopyrite surface. The morphological change of dixanthogen patches at elevated temperatures has a more significant impact than changes in the amount of adsorption species. Increasing temperature within a certain range is beneficial for the collector's performance by increasing flotation recovery.
\end{abstract}

Keywords: flotation; xanthate; temperature; chalcopyrite; AFM; FTIR; contact angle

\section{Introduction}

In the copper extraction industry, porphyry chalcopyrite is usually separated from gangue, such as silica and silicates, by flotation using xanthate as a collector. A deep understanding on the flotation behavior is needed to further improve separation performance and many research works have been undertaken to understand the chalcopyrite flotation mechanism. It is now well known that for xanthate, the most widely applied collector for sulfides flotation, the oxidation of xanthate into dixanthogen on the mineral surface is the mechanism of the flotation of chalcopyrite using xanthate [1].

Plenty of test methods have been applied to figure out the impact of specific parameters on chalcopyrite flotation. Guo and Yen [2] conducted a series studies on the hydrophobicity of the chalcopyrite surface controlled by surface oxidation potential. Contact angle measurement was applied together with electrochemical control. It was reported that chalcopyrite could be hydrophobic only within a certain range of oxidation potential. Proper treatment with xanthate would enlarge the hydrophobic potential range. Leppinen [3] investigated xanthate adsorption on sulfides by Fourier transform infrared (FTIR) spectroscopy and micro-flotation tests with different $\mathrm{pH}$ and xanthate concentrations. It was reported that metal xanthate and dixanthogen were observed and the different absorption density brought by varied solutions can be discerned through comparison of peak heights.

Kartio et al [4] used X-Ray Photoelectron Spectroscopy (XPS) to characterize the mineral surface from flotation tests. The XPS spectra reported showed chemisorption of xanthate ions on chalcopyrite 
surface with no evidence of dixanthogen being formed on the pyrite surface. Rest potential was also below the critical value for dixanthogen formation. However, Zhang et al. [5-8] recently employed an atomic force microscope (AFM) imaging method to get visualized data of chemical adsorption on mineral surface. With the help of an AFM fluid cell, one can study in situ adsorption of the chemicals on the mineral surface in the solution. These results showed that dixanthogen, which was usually in an oily liquid form at room temperature and atmosphere, was the most responsible chemical for increasing the surface hydrophobicity of chalcopyrite. Some techniques such XPS, which require a high vacuum working condition, could hardly detect dixanthogen without cooling the measuring system to a low temperature due to the evaporation of organics in the vacuum. A most recent Raman spectroscopy work by Vazquez-Sanchez et al. [9] also showed that dixanthogen was the species adsorbing on chalcopyrite.

In spite of the fact that many efforts have been made regarding the factors (concentration, $\mathrm{pH}$, oxidation potential, etc.) that could affect the collector's performance on chalcopyrite flotation process, comparatively much less work was available for the temperature effect. In many cases, temperature is usually regarded as a constant (room temperature), although it is considered an important factor during flotation.

Lin [10] summarized the factors affected by seasonal variation of temperature during flotation process in South Africa. Annually the low temperature $\left(12^{\circ} \mathrm{C}\right)$ impeded the floatability while at ambient temperature $\left(28^{\circ} \mathrm{C}\right)$ the metal recovery was higher than that of winter. The related factors affected by low temperature could be the viscosity of water, fines content, setting rates of particles, solubility of reagents and residence time. These factors impaired the efficiency of milling in the beginning and could affect the final metal recovery of flotation. Improvement actions like reducing feeds, preheating pulp and higher comminution energy could help prevent the efficiency from going down with temperature, whereas more cost was needed. Moreover, the flotation parameters were also changed by the variation of temperature such as reaction kinetics, selectivity of adsorption, dissolved oxygen, froth properties, surface tension, contact angle and HLB value.

$\mathrm{O}^{\prime}$ Connor and Mills [11] studied the kinetics of pyrite flotation by changing the temperature from $3{ }^{\circ} \mathrm{C}$ to $44{ }^{\circ} \mathrm{C}$. It was reported that when temperature increased, both the recovery and the grade of pyrite increased. The improvement was explained based on the reduction of viscosity, which would weaken the association between gangue particles and the medium, thus the gangue particles had more possibility to fall in the pulp. As temperature increased, a reduction of bubble size (namely larger surface area) was observed due to lower viscosity. The improved flotation recovery could also be partially ascribed to the enlarged surface area for attachment.

Mustafa et al. [12] studied the adsorption of xanthate on chalcopyrite and reported that xanthate was stable under the given adsorption conditions ( $2.58 \%$ decomposition per day). The amount of absorbed xanthate gradually increased with temperature increasing for all the tested $\mathrm{pH}$, and the increase was attributed to the surface activation and enhanced solubility of xanthate. The reported FTIR results showed that copper xanthate was observed at low temperature, whereas dixanthogen emerged at elevated temperature. It was also proposed that copper xanthate was converted to dixanthogen at high temperature.

Strong et al. [13] conducted research on the properties of xanthate in sulfides flotation at elevated temperatures. The research was carried out by detecting xanthate concentration in pulp after flotation and also on the sulfide surface in concentrate. It was observed that the amyl xanthate concentration in solution after flotation was lower at higher temperature than that of room temperature. Correspondingly, the diamyl dixanthogen and copper xanthate concentration on sulfides surface increased significantly with elevated temperature. It was claimed that at high temperature, the extra consumption of xanthate was due to the accelerated formation of dixanthogen and enhanced decomposition into carbon sulfide and copper xanthate. Consequently, the recovery of copper was improved by high temperature at which the concentration of hydrophobic species was higher. 
The above literature shows that temperature does impact froth flotation in various aspects. Unlike other well defined flotation parameters ( $\mathrm{pH}$, collector, frother), temperature still lacks systematic and comprehensive studies. Although the temperature parameter is normal in daily life and can be controlled with convenience, it is one of the most interactive parameters in a flotation system. The temperature variation can be reflected in electrochemistry, surface chemistry, solution chemistry, etc. Moreover, the impact of temperature can be significantly different from case to case (e.g., different ores). Despite the complexity presented, we can still figure out the possible mechanism of the temperature effect on flotation by employing a detailed, multi-scale and systematical study.

This investigation was carried out in order to study the temperature effect on the xanthate's adsorption on chalcopyrite surface and, therefore, chalcopyrite flotation. The tested temperatures are specifically selected from $25^{\circ} \mathrm{C}$ to $65^{\circ} \mathrm{C}$ because of the potential high temperature flotation process of Resolution Copper ore, which is mined from a deep and hot underground mine. The temperature of the run of mine ore (ROM) is much higher than that of the ore usually processed in a typical open-pit copper mine. During the transportation, crushing and grinding processes, the ore temperature may decrease a little bit in ambient conditions. However, the hot climate of Southern Arizona can help maintain the temperature of ROM ore before it is sent to the concentrator. The ore temperature will still be quite high when the ore is processed in conventional flotation cells. Because temperature does impact flotation recovery, as shown by the literature review, it is therefore critical to carry out a systemic study on the flotation of Resolution Copper ore at elevated temperatures and clarify the mechanism of temperature effect on flotation. Moreover, it is expected that we can provide a possible explanation for and advice upon the issues related to temperature variance in industry practice.

\section{Materials and Methods}

\subsection{Materials}

Samples of high-purity chalcopyrite were obtained from Wards Natural Science Establishment, Rochester, NY, USA. Chalcopyrite samples were finely polished to expose a fresh surface, then cleaned by rinsing thoroughly with ethanol and deionized water, and finally blown dry by nitrogen gas for further surface characterization for AFM, FTIR-ATR and contact angle measurements. The chalcopyrite samples of high purity (microflotation samples) were also crushed and ground into the size of $100 \%$ passing 100 mesh. The ground samples were then screened by a RX-29 Ro-Tap test sieve shaker with Tyler series sieves. For lab-scale flotation the samples $(1.51 \% \mathrm{Cu}, 5.88 \%$ Fe $0.029 \% \mathrm{Mo}, 5.23 \% \mathrm{~S}$ in weight percentage) were taken from Superior, AZ, a chalcopyrite ore deposit belonging to the Resolution Copper Company. The drill hole samples were mixed and crushed to -6 mesh at SGS, Tucson, AZ. The deionized water was used in all the experimental work, which has a conductivity of $18.2 \mathrm{M} \Omega \cdot \mathrm{cm}$ at $25^{\circ} \mathrm{C}$ and a surface tension of $72.5 \mathrm{mN} / \mathrm{m}$ at $25^{\circ} \mathrm{C}$. The ethanol (100\% pure) was prepared by Decon Lab, Inc. The liquid nitrogen and nitrogen gas were prepared by the Cryogenics and Gas Facility, University of Arizona, Tucson, AZ. Potassium amyl xanthate (PAX) (>98\%) was obtained from TCI Inc. for the surface analysis study. $\mathrm{Ca}(\mathrm{OH})_{2}(>98 \%)$ was obtained through Alfa Aesar and used without further purification. Industry collectors and frother were applied towards the lab flotation tests. The $\mathrm{pH}$ of xanthate solution was neutral. For each test xanthate solutions were freshly made before experimental measurement.

\subsection{Contact Angle Measurement}

Sessile drop experiments were carried out by a KSV CAM 101 goniometer (KSV Instruments Ltd., Helsinki, Finland) to determine water contact angles on mineral surface. Samples of chalcopyrite were prepared on $3 \mathrm{~cm} \times 3 \mathrm{~cm}$ plates before further treatment. The fresh surface of sample was soaked in xanthate solution of different concentrations and temperatures for specific time after polishing, rinsing sample surface with ethanol and water, and blowing the surface with $\mathrm{N}_{2}$ gas in sequence. The reacted chalcopyrite sample surface was further dried by gentle nitrogen gas flow. A drop of deionized water 
was then dripped to sample surface and a picture was taken within $1 \mathrm{~min}$. The CAM 2008 software was then used to analyze the droplet morphology and give the contact angle values. In total, six contact angle values were recorded and averaged for each data point.

\subsection{Fourier Transform Infrared Spectroscopy-Attenuated Total Reflectance (FTIR-ATR) Measurement}

A Nicolet 6700 Fourier transform infrared spectrometer (Thermo Fisher Scientific, Waltham, MA, USA) equipped with the Smart iTR accessory was used to collect mid-infrared spectra. The system was equipped with a liquid-nitrogen cooled DTGS KBr detector and also a diamond ATR crystal with an angle of incidence of $45^{\circ}$ to detect signals. Fresh mineral surface was pressed and fastened towards the ATR crystal to collect background spectra first. A sample spectra was collected after the chalcopyrite sample had been soaked in xanthate solutions of different concentrations and temperatures for a specific time. The intensities in the FTIR spectra were shown as a relative value under the same scale for the sake of the complexity of reflection spectroscopy. All spectra were collected at room temperature and there was no further treatment of spectra except baseline correction.

\subsection{Atomic Force Microscopy (AFM) Surface Image Measurement}

AFM surface image measurements were carried out in contact mode using a Digital Instrument Nanoscope IIId AFM (Veeco, CA, USA). For this specific temperature effect study, an AFM temperature control package, which included a liquid cooled scanner with a $125 \mu \mathrm{m} \times 125 \mu \mathrm{m} \times 5 \mu \mathrm{m}$ range (XYZ), a plug-in heater element $\left(-35\right.$ to $\left.100{ }^{\circ} \mathrm{C}\right)$, a pump with damper and reservoir, and a TAC heater controller, was applied to collect the surface images at a temperature ranging from $0{ }^{\circ} \mathrm{C}$ to $70{ }^{\circ} \mathrm{C}$. Silicon nitride NP-20 cantilevers with nominal spring constant of $0.12-0.58 \mathrm{~N} / \mathrm{m}$ were obtained from Veeco, CA. A $1.2 \mathrm{~cm} \times 1.2 \mathrm{~cm}$ mineral sample was used for measurement. For the study of mineral surface in water, surface image measurements were conducted right after the nanopure water was injected into an AFM fluid cell. After the surface image data was collected, a $10 \mathrm{~mL}$ solution of a specific xanthate concentration was flushed through the liquid cell and the AFM measurement was commenced after the exposure of the mineral plate to the xanthate solution for a specific time. No image modification other than flattening was conducted towards the image.

\subsection{Hallimond Tube Microflotation Tests}

The microflotation samples, with a particle size between -100 mesh and +400 mesh, were mixed evenly before tests. The feed weight for each test was $1 \mathrm{~g}$. According to the design of Hallimond tube, the optimal solution volume was determined at $100 \mathrm{~mL}$ per test. A magnetic stirrer and heater was placed beneath the Hallimond tube for heating and stirring. The mineral sample was added in the tube, and then a tiny stirrer was put in the tube before the solution was injected. The mixing time was 5 min. A $0.02 \mathrm{~L} / \mathrm{min}$ air flow was induced to start the flotation process and the flotation time was controlled at 2 min.

\subsection{Lab Flotation Tests}

The lab-scale flotation tests were conducted on a Denver D-12 flotation machine (Mesto, Helsinki, Finland). The ore sample was initially crushed to $100 \%$ passing 10 mesh and packaged into $1 \mathrm{~kg}$ bags to prevent the ore from oxidation. A $1 \mathrm{~kg}$ sample was mixed with $750 \mathrm{~mL}$ water (pH 8.5-9, with $0.1 \mathrm{lb} /$ ton PAX being added) and ground for $8 \mathrm{~min}$ in an $8^{\prime \prime} \times 8^{\prime \prime}$ ball mill manufactured by Legend Inc., Sparks, NV, USA. Solid content during grinding was around $60 \%$. The particle size after grinding was controlled at $80 \%$ passing 100 mesh. All the material in the ball mill was transferred into the $2.5 \mathrm{~L}$ flotation cell (solid content 33\%). The pulp was conditioned by $\mathrm{Ca}(\mathrm{OH})_{2}$ to keep the $\mathrm{pH}$ around 8.5-9. Frother (methyl isobutyl carbinol (MIBC), $0.07 \mathrm{lb} / \mathrm{ton}$ ) was then added and mixed for another $1 \mathrm{~min}$. The closed impeller was set at $1800 \mathrm{rpm}$. The flotation time was determined at $10 \mathrm{~min}$. 


\subsection{Surface Tension Measurements}

Pendant drop experiments were carried out by a KSV CAM 101 goniometer to determine the surface tension of specific solutions. The biggest drop that could hang from a syringe tip was made and a picture was taken. The shape of the drop was determined from the balance of forces that include the surface tension of that liquid. The CAM 2008 software recorded the shape, fitted the curve and gave results based on the equation below:

$$
\gamma=\frac{\Delta \rho \times \mathrm{g} \times R_{0}}{\beta}
$$

where $\gamma$ is surface tension; $\beta$ is shape factor; $\Delta \rho$ is the difference in density between fluids at interface, $\mathrm{g}$ is gravitational constant; $R_{0}$ is radius of drop curvature at apex. Due to the fast cooling down speed of droplet, the picture was captured within $30 \mathrm{~s}$ after the droplet was formed.

\section{Results}

\subsection{Contact Angle Results}

The contact angle results of the chalcopyrite surface after soaking in PAX solutions of different concentrations were displayed as a function of adsorption time in Figure 1. The water contact angle value of the fresh polished chalcopyrite surface was $55^{\circ}$. Once the contact angle of chalcopyrite bare surface was obtained, 3 different concentrations of PAX solutions $\left(5 \times 10^{-5} \mathrm{M}, 1 \times 10^{-4} \mathrm{M}\right.$ and $5 \times 10^{-4} \mathrm{M}$ ) were applied in soaking freshly polished surface of chalcopyrite plates. Different adsorption time ( $5 \mathrm{~min}, 10 \mathrm{~min}$ and $30 \mathrm{~min}$ ) was applied for all 3 concentration series. Figure 1 shows that the contact angle of the chalcopyrite surface treated with $5 \times 10^{-5} \mathrm{M}$ had an increasing trend as the soaking time increased. With 5 min soaking time, the water contact angle value of the chalcopyrite surface could rise from $55^{\circ}$ to $77^{\circ}$. Given 10 min soaking time, the contact angle further increased to $80^{\circ}$. Finally, as the soaking time was extended to $30 \mathrm{~min}$, a maximum contact angle value of $82^{\circ}$ was obtained. Similarly, when PAX concentration increased to $1 \times 10^{-4} \mathrm{M}$, the water contact angle value of the chalcopyrite surface was $78^{\circ}, 79^{\circ}$ and $82^{\circ}$ respectively for $5 \mathrm{~min}, 10 \mathrm{~min}$ and $30 \mathrm{~min}$ soaking time. Although the concentration of $5 \times 10^{-4} \mathrm{M}$ PAX was 10 times $5 \times 10^{-5} \mathrm{M}$ PAX, the hydrophobicity of chalcopyrite surfaces had little difference, since the contact angle values were $79^{\circ}$ for $5 \mathrm{~min}, 80^{\circ}$ for $10 \mathrm{~min}$ and $84^{\circ}$ for $30 \mathrm{~min}$ soaking time. Taking the error bars displayed in consideration, the 3 data series at different PAX concentrations were indistinguishable.

Figure 2 displays the effect of elevated temperature on water contact angle of chalcopyrite surface treated with different concentrations of PAX solutions; 5 min was used as standard soaking time since the results in Figure 1 proved that 5 min was enough for the observation of significant difference in contact angle results. The temperatures employed in this study were $25^{\circ} \mathrm{C}, 40^{\circ} \mathrm{C}$ and $60^{\circ} \mathrm{C}$. To confirm the temperature effect on the hydrophobicity of chalcopyrite bare surface, chalcopyrite pellets were soaked in distilled water and heated at different temperatures (i.e., PAX $0 \mathrm{M}$ ). The results showed that there was no significant increase in contact angle with elevated temperature. However, when the concentration of PAX solution was $1 \times 10^{-4} \mathrm{M}$, the contact angle results were altered significantly with the variation of temperatures. The contact angle raised from $77^{\circ}$ at $25^{\circ} \mathrm{C}$, to $87^{\circ}$ at $40{ }^{\circ} \mathrm{C}$ and finally up to $93^{\circ}$ at $60^{\circ} \mathrm{C}$. A significant temperature effect on chalcopyrite contact angle was also observed at a higher concentration of $5 \times 10^{-4} \mathrm{M}$. Initial contact angle at room temperature was $79^{\circ}$, which increased to $85^{\circ}$ after soaking in $40^{\circ} \mathrm{C}$ solution and reached up to maximum contact angle of $96^{\circ}$ at $60^{\circ} \mathrm{C}$. In general, contact angle values increased with elevated temperatures after contacting with xanthate solutions. 


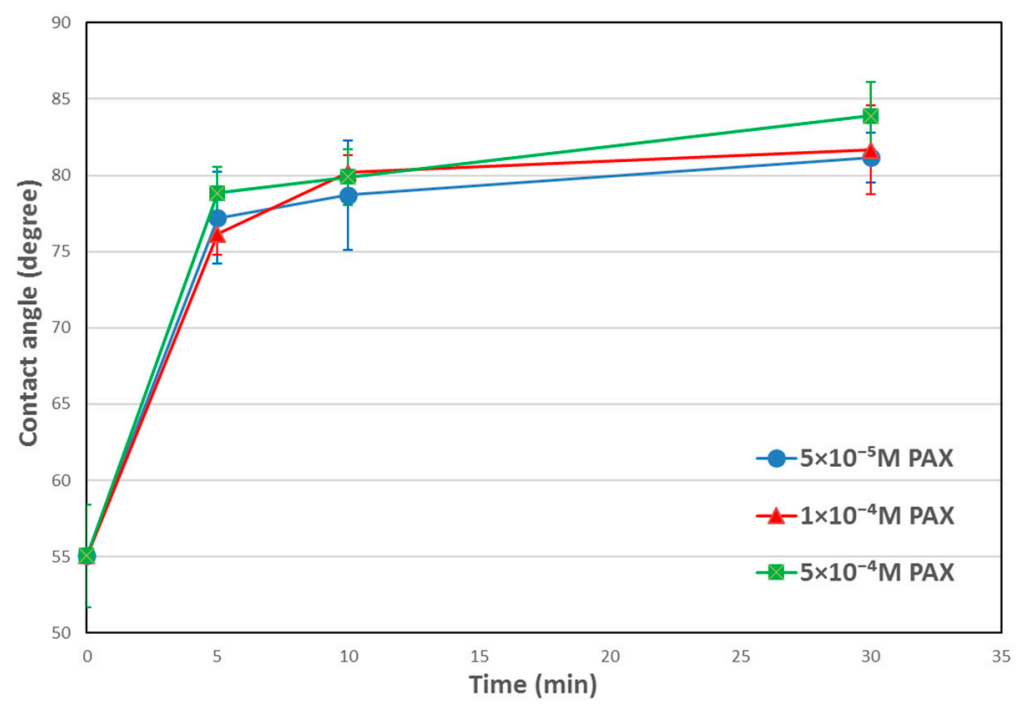

Figure 1. Contact angle results of chalcopyrite surface after contact with potassium amyl xanthate (PAX) solution of different concentrations for $5 \mathrm{~min}, 10 \mathrm{~min}$ and $30 \mathrm{~min}$ at $25^{\circ} \mathrm{C}$.

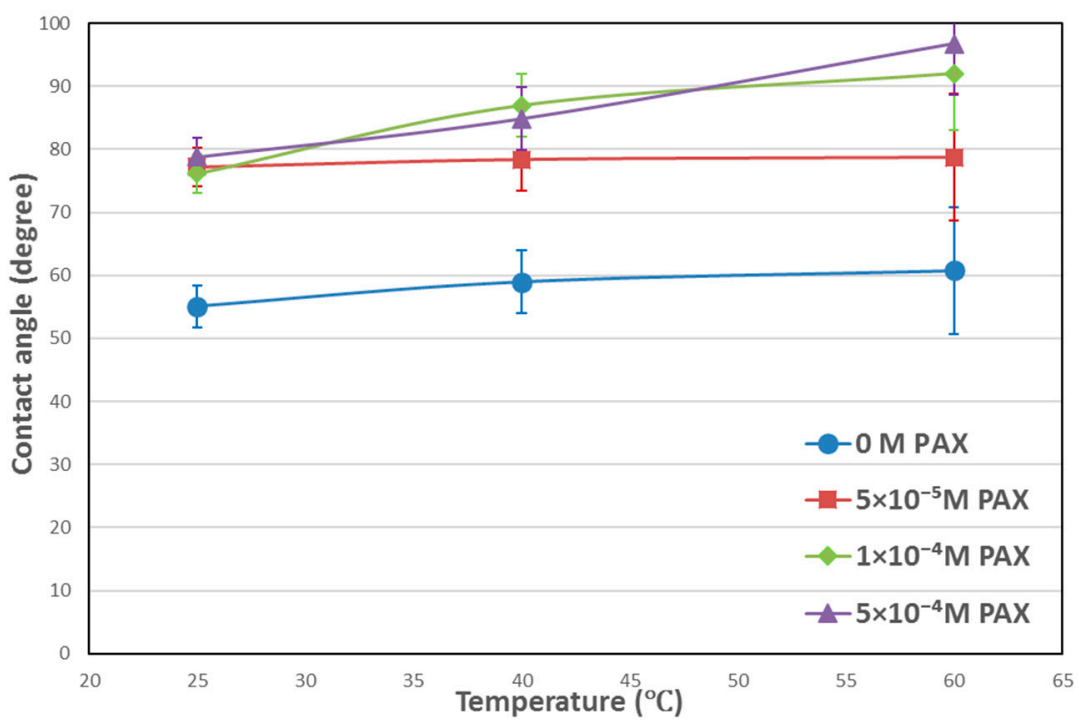

Figure 2. Contact angle results of chalcopyrite surface after contacting with PAX solution of different concentrations for 5 mins at $25^{\circ} \mathrm{C}, 40^{\circ} \mathrm{C}$, and $60^{\circ} \mathrm{C}$.

\subsection{Microflotation Results}

Table 1 shows the results of microflotation tests with high-purity chalcopyrite. Chalcopyrite particles were mixed and agitated with solutions of different PAX concentrations $\left(0 \mathrm{M}, 5 \times 10^{-5} \mathrm{M}\right.$, $1 \times 10^{-4} \mathrm{M}$ and $5 \times 10^{-4} \mathrm{M}$ ). Flotation started after $5 \mathrm{~min}$ of conditioning. The floated material was collected in the concentrated stem and the unfloated particles were regarded as tailings. Natural chalcopyrite of high purity showed very high floatability without collectors. The chalcopyrite particles attached with the air bubbles very well in a Hallimond tube. In distilled water without a collector, the microflotation recovery of chalcopyrite was around $80 \%$ in the temperature range from $25^{\circ} \mathrm{C}$ to $60^{\circ} \mathrm{C}$. With the addition of $5 \times 10^{-5} \mathrm{M}$ PAX solution, the microflotation recovery was enhanced close to $100 \%$, and the elevated temperatures had no detrimental impact on the final recovery. A further rise in collector concentration $\left(1 \times 10^{-4} \mathrm{M}\right.$ and $\left.5 \times 10^{-4} \mathrm{M}\right)$ did not imply any difference from the data series of $5 \times 10^{-5} \mathrm{M}$ PAX solution. 
Table 1. Hallimond tube flotation recovery of chalcopyrite.

\begin{tabular}{cccc}
\hline PAX Concentration & \multicolumn{3}{c}{ Recovery (\%) } \\
\hline & $25^{\circ} \mathrm{C}$ & $40{ }^{\circ} \mathrm{C}$ & $60{ }^{\circ} \mathrm{C}$ \\
$0 \mathrm{M}$ & 77.97 & 83.03 & 83.44 \\
$5 \times 10^{-5} \mathrm{M}$ & 98.11 & 99.22 & 99.99 \\
$1 \times 10^{-4} \mathrm{M}$ & 97.38 & 98.29 & 99.98 \\
$5 \times 10^{-4} \mathrm{M}$ & 98.10 & 97.99 & 99.97 \\
\hline
\end{tabular}

\subsection{FTIR Results}

Figures 3 and 4 showed the FTIR spectra of chalcopyrite surface species after contacting with PAX solutions of various concentrations at different temperatures for $2 \mathrm{~h}$. Absorbance of spectra collected at shorter contact time was minimal and comparison among spectra was difficult. For all data series, the spectra had the same major characteristic peaks with wavenumber around $1260 \mathrm{~cm}^{-1}$ and $1020 \mathrm{~cm}^{-1}$. Figure 3 displayed the concentration effect of PAX adsorption on the chalcopyrite surface by means of FTIR spectra. For each temperature tested, 3 spectra were collected at different PAX solutions and displayed in the same figure. The height of characteristic peak (absorbance) was a good parameter to evaluate the amount of product absorbed on mineral surface relatively. One can clearly see that at room temperature, the peak height of surface product produced on chalcopyrite surface after treated by PAX $1 \times 10^{-4} \mathrm{M}$ solution was about two times that produced by PAX $5 \times 10^{-5} \mathrm{M}$ solution. Also peak absorbance of surface product formed by PAX $5 \times 10^{-4} \mathrm{M}$ solution was 6 times of that produced by PAX $5 \times 10^{-5} \mathrm{M}$ solution. Thus, the ratio of peak absorbance was approximately 1:2:6 corresponding to the PAX concentration of $5 \times 10^{-5} \mathrm{M}, 1 \times 10^{-4} \mathrm{M}$ and $5 \times 10^{-4} \mathrm{M}$. The effect of PAX concentration was also verified by spectra collected at $40{ }^{\circ} \mathrm{C}$ and $60{ }^{\circ} \mathrm{C}$. Figure 4 is organized by stacking together the spectra obtained with different temperatures for each concentration series. There was no obvious difference being observed among the 3 spectra collected at different temperatures for each PAX concentration. The absorbance of characteristic peaks was almost the same even though the temperature was elevated.

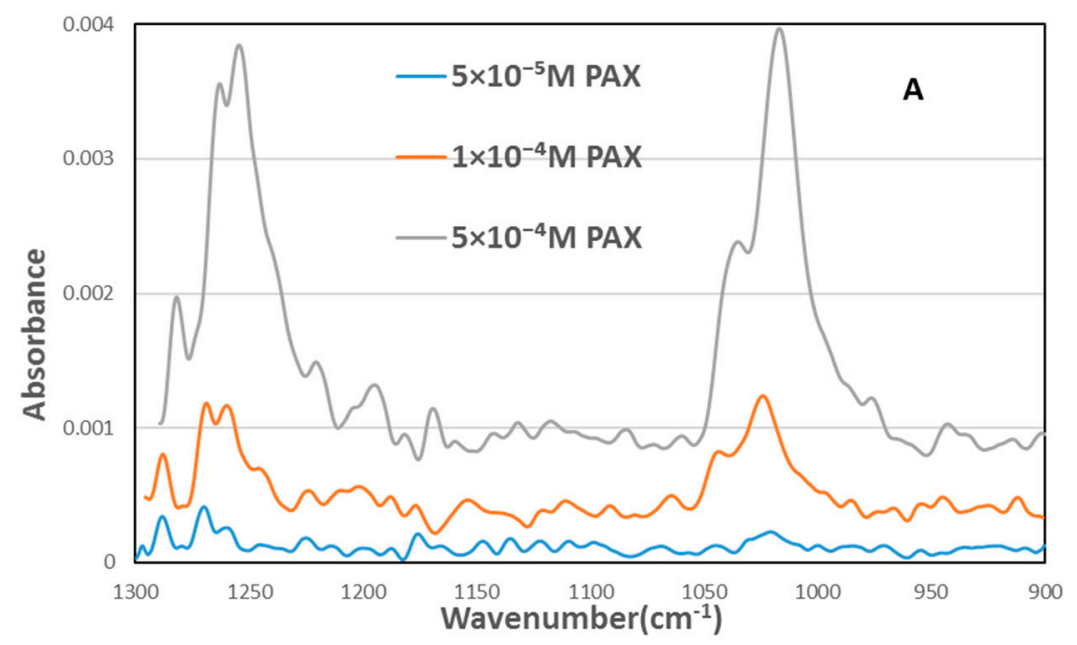

Figure 3. Cont. 

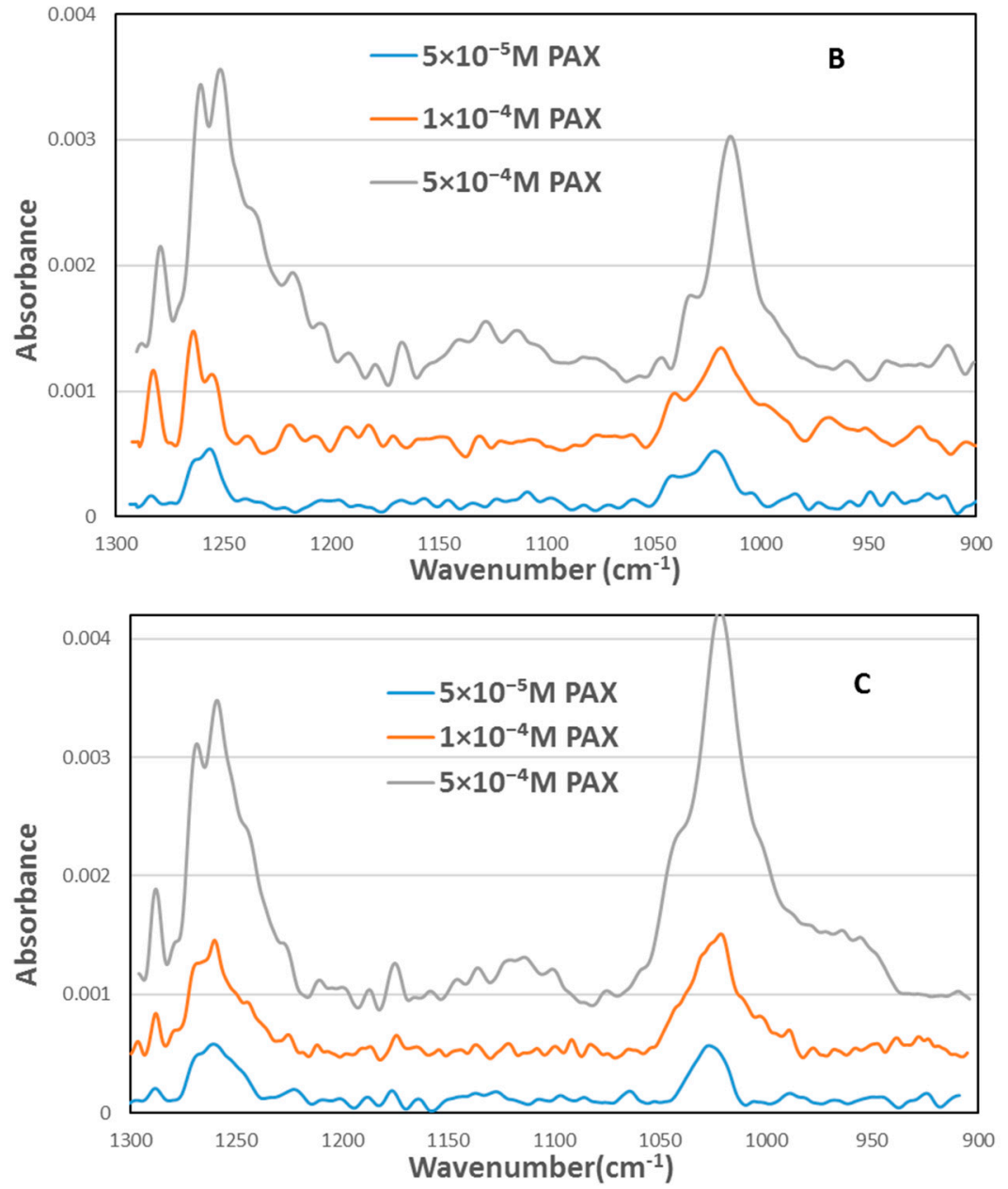

Figure 3. Fourier transform infrared (FTIR) spectra of chalcopyrite surface after treated with different PAX solutions for $2 \mathrm{~h}$ at (A) $25^{\circ} \mathrm{C}$; (B) $40{ }^{\circ} \mathrm{C}$; (C) $60^{\circ} \mathrm{C}$.

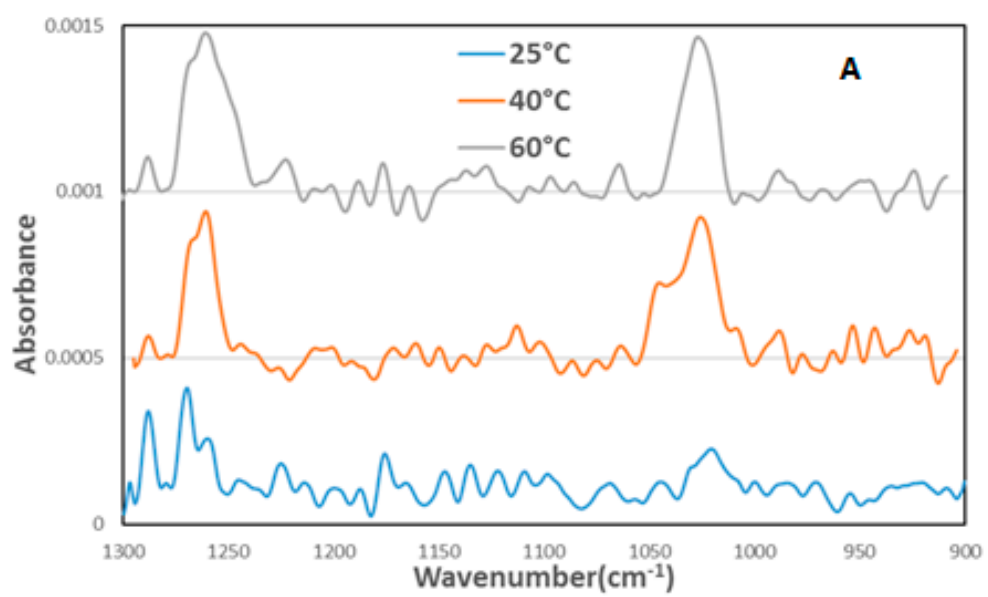

Figure 4. Cont. 

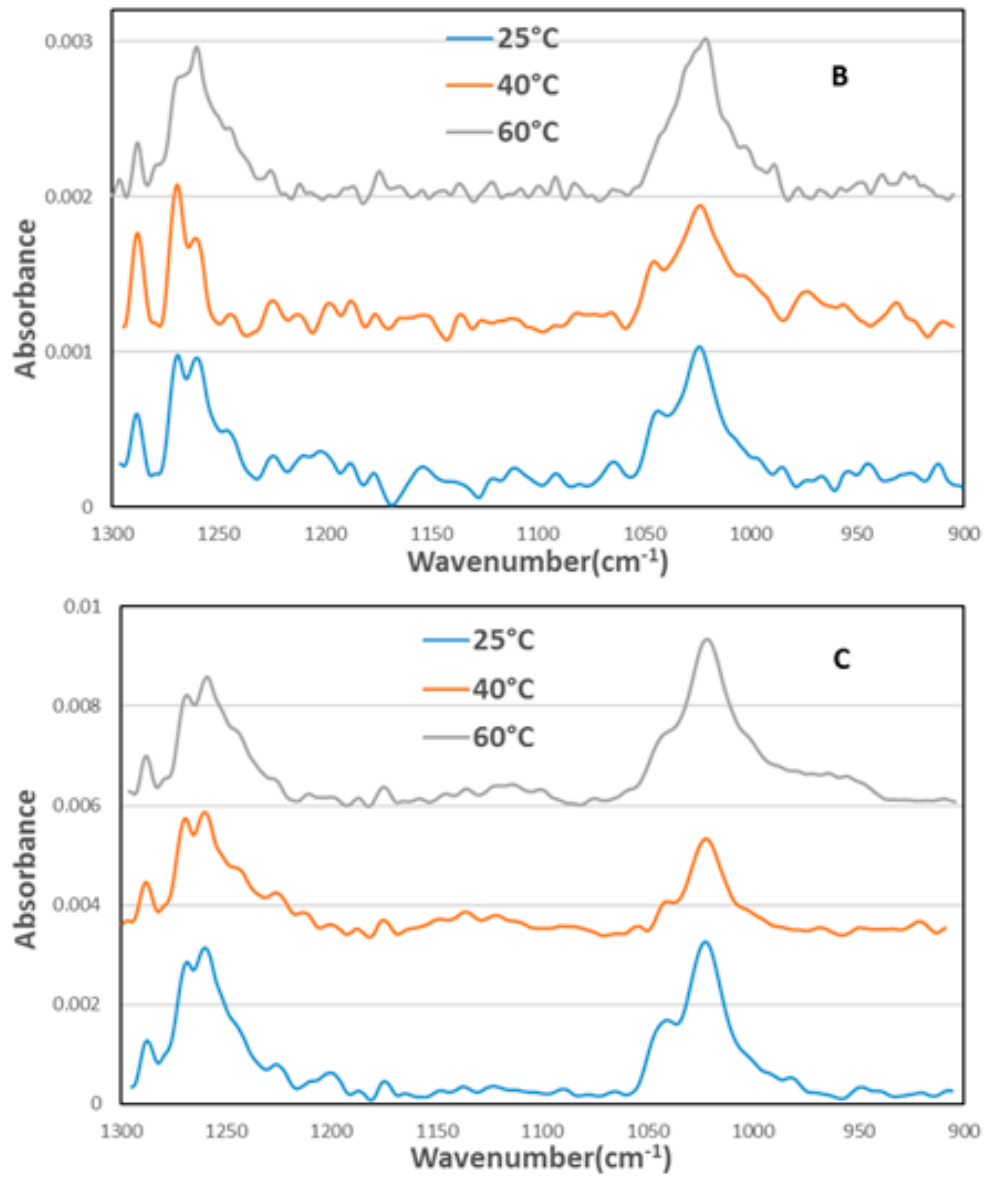

Figure 4. FTIR spectra of chalcopyrite surface after treated at different temperatures for $2 \mathrm{~h}$ with (A) PAX $5 \times 10^{-5} \mathrm{M}$; (B) PAX $1 \times 10^{-4} \mathrm{M}$; (C) $5 \times 10^{-4} \mathrm{M}$.

\subsection{AFM Results}

Figure 5 shows the AFM images of a chalcopyrite surface soaked in $5 \times 10^{-4} \mathrm{M}$ xanthate solutions at different temperatures. Figure $5 \mathrm{~A}$ is the $30 \mu \mathrm{m} \times 30 \mu \mathrm{m}$ image with a $20 \mathrm{~nm}$ data scale obtained at room temperature, i.e., $25^{\circ} \mathrm{C}$, after the sample contacted solution for $10 \mathrm{~min}$. It is clearly seen that many patches adsorbed on chalcopyrite surface. As shown by Figure $5 B$, when temperature was elevated to $30{ }^{\circ} \mathrm{C}$, some patches still existed on sample surface. It is worth mentioning that, as shown by the scan lines, the patches were very soft and the adsorbate was a little bit disturbed by the AFM probe even though a minimal scan force was applied in scanning. Figure $5 \mathrm{C}$ shows that the dot-like patches were all gone when temperature was elevated to $45^{\circ} \mathrm{C}$. Instead, a lot of irregular strips appeared on the sample surface. As shown by Figure 5, temperature did make changes in the morphology of the patches. In Figure $5 \mathrm{~A}$ at room temperature, a lot of patches appear on the chalcopyrite surface when it contacts the collector solution. This result was in line with those reported in previous investigations $[5,6]$. When temperature was increased to $30^{\circ} \mathrm{C}$, the patches still existed on mineral surface in spite of the fact that they became much "softer". When temperature was further increased to $45^{\circ} \mathrm{C}$, as shown by Figure $5 \mathrm{C}$, the adsorbate became so soft that it lost the round shape and presented as strips on mineral surface because of the drag force exerted by an AFM probe. On the other hand, the temperature effect observed on the patches' morphology can be well explained by the change in the "hardness" of oil substance with temperature. That is, on chalcopyrite surface with the presence of oxygen in solution, xanthate can be oxidized into dixanthogen, i.e., the round patches as shown by Figure 5A. Under ambient conditions, i.e., room temperature and normal pressure, dialkyl dixanthogen was usually in a liquid form and the melting point of dixanthogen, was about $28^{\circ}$ [14] to $32^{\circ}$ [15]. The low melting point suggested that dixanthogen should be a "soft" solid at room temperature and was usually an oily substance 
when extracted at room temperature [14]. At a low temperature, the patches were flat with smooth and round edges. It fitted well with the fact that oily dixanthogen was in general insoluble in water, and the circular boundary was the direct result of the high interfacial tension between hydrophobic dixanthogen and water. When temperature increased, the "hardness" of dixanthogen decreased and the patches became "soft". It was very difficult for the patches to keep its original shape under an AFM probe, even though a minimal scan force was applied. Therefore, at a high temperature, dixanthogen appeared as strips instead of round patches on the AFM images.
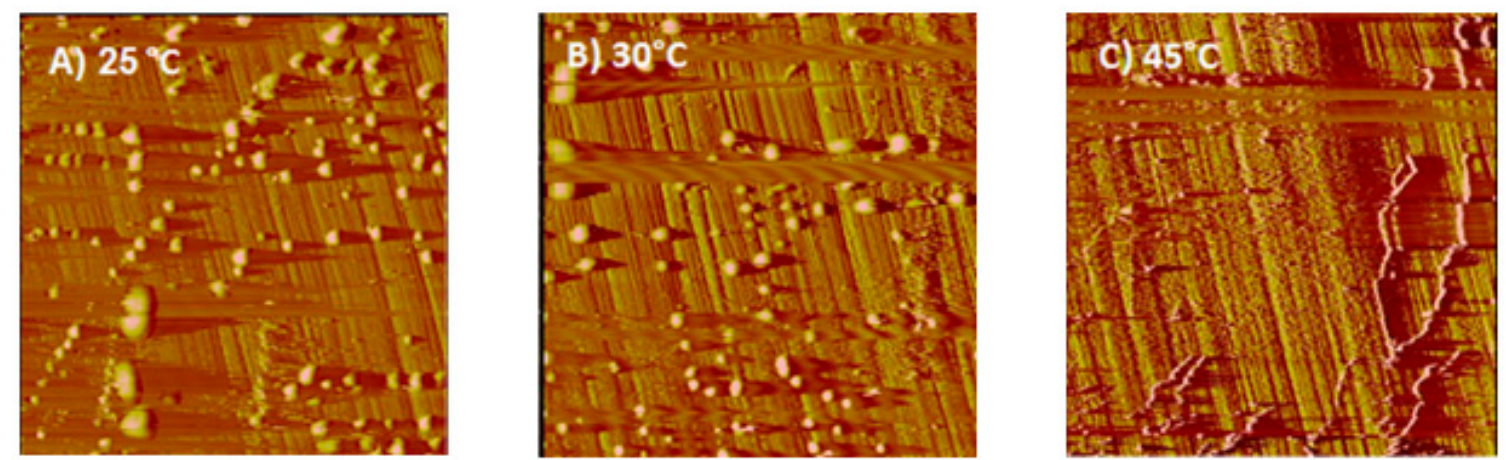

Figure 5. The $30 \mu \mathrm{m} \times 30 \mu \mathrm{m}$ atomic force microscope (AFM) deflection images with a $20 \mathrm{~nm}$ scale of a chalcopyrite surface soaked in $5 \times 10^{-4} \mathrm{M}$ xanthate solutions at different temperatures (A) $25^{\circ} \mathrm{C}$; (B) $30{ }^{\circ} \mathrm{C}$; (C) $45^{\circ} \mathrm{C}$.

\subsection{Lab-Scale Flotation Results}

To figure out the temperature effect in flotation practice and clarify the concerns in previous work, lab flotation tests were conducted and the results are summarized in Figure 6 and Table 2. The major commercial mineral of this ore was chalcopyrite and the byproducts were molybdenite and pyrite (high-grade pyrite is economically recoverable). The baseline flotation temperature was set at $25{ }^{\circ} \mathrm{C}$. The optimized $\mathrm{Cu}$ recovery at room temperature was $88.87 \%$. With the increase of temperature, the flotation recovery was also enhanced and such were the cases for byproducts. Since the temperature may drop during the flotation process (even with heat loss protection), pulps of all tests were heated $5{ }^{\circ} \mathrm{C}$ more to ensure the flotation temperature was high enough above the target temperature throughout the flotation test.

As shown by Figure 6 and Table 2, when temperature ranged from $25^{\circ} \mathrm{C}$ to $55^{\circ} \mathrm{C}, \mathrm{Cu}$ recovery increased gradually with elevated temperature. When the temperature was as high as $65{ }^{\circ} \mathrm{C}$, the increment of copper recovery with increased temperature was negligible and this conclusion can also be observed in the data series of Fe recovery. The Mo recovery had an overall rising trend with temperature as the other 2 elements. However, the detailed increment amplitudes were different from $\mathrm{Cu}$ and $\mathrm{Fe}$ at each temperature gradient. The grade of copper concentrate kept steady throughout the whole temperature ranges and such were the cases for byproducts. 


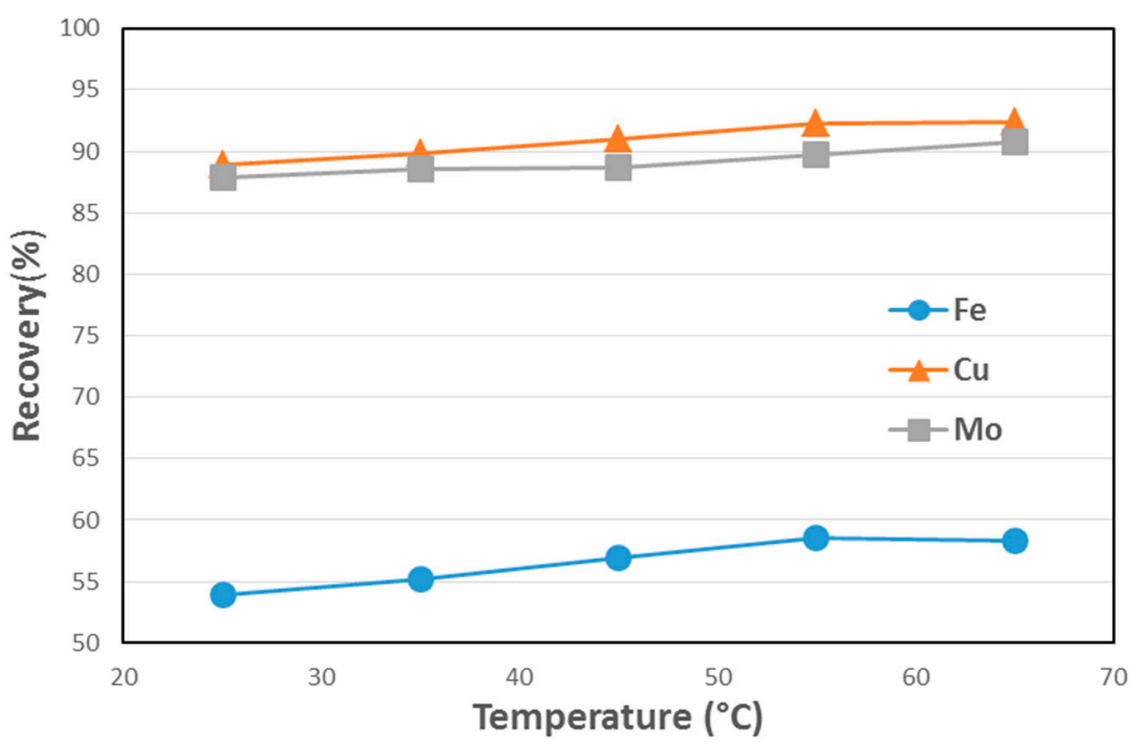

Figure 6. Lab flotation tests results: multi-element recovery at different temperatures.

Table 2. Lab flotation recovery and grade details.

\begin{tabular}{ccccccc}
\hline $\begin{array}{c}\text { Temperature } \\
\left({ }^{\circ} \mathbf{C}\right)\end{array}$ & $\begin{array}{c}\text { Cu Recovery } \\
\mathbf{( \% )}\end{array}$ & $\begin{array}{c}\text { Cu Grade } \\
\mathbf{( \% )}\end{array}$ & $\begin{array}{c}\text { Mo Recovery } \\
\mathbf{( \% )}\end{array}$ & $\begin{array}{c}\text { Mo Grade } \\
\mathbf{( \% )}\end{array}$ & $\begin{array}{c}\text { Fe Recovery } \\
\mathbf{( \% )}\end{array}$ & $\begin{array}{c}\text { Fe Grade } \\
(\mathbf{\%})\end{array}$ \\
\hline 25 & 88.87 & 8.6 & 87.91 & 0.18 & 53.93 & 22.8 \\
35 & 89.95 & 8.8 & 88.52 & 0.18 & 55.21 & 22.4 \\
45 & 91.00 & 8.9 & 88.64 & 0.18 & 56.90 & 23.7 \\
55 & 92.30 & 8.3 & 89.74 & 0.17 & 58.51 & 23.0 \\
65 & 92.41 & 8.8 & 90.73 & 0.18 & 58.27 & 23.7 \\
\hline
\end{tabular}

\subsection{Surface Tension Results}

Figure 7 displayed the relationship between temperature and surface tension of PAX solution. Standard water surface tensions at different temperatures were extracted and plotted in this figure. The surface tension showed a negative linear relationship with temperature. Surface tension of $5 \times 10^{-4} \mathrm{M}$ PAX solution was measured at $25^{\circ} \mathrm{C}, 40^{\circ} \mathrm{C}$, and $60^{\circ} \mathrm{C}$. Since PAX also worked as surfactant in water, the surface tension at room temperature was lower than standard water surface tension. The surface tensions of PAX solution were also lower than those of standard water at $40^{\circ} \mathrm{C}$ and $60^{\circ} \mathrm{C}$. However, the reducing trend was not as linear as water surface tension was with temperatures. As the temperature rose from $40^{\circ} \mathrm{C}$ and $60^{\circ} \mathrm{C}$, the drop in surface tension became less than that dropping from $25^{\circ} \mathrm{C}$ to $40{ }^{\circ} \mathrm{C}$. 


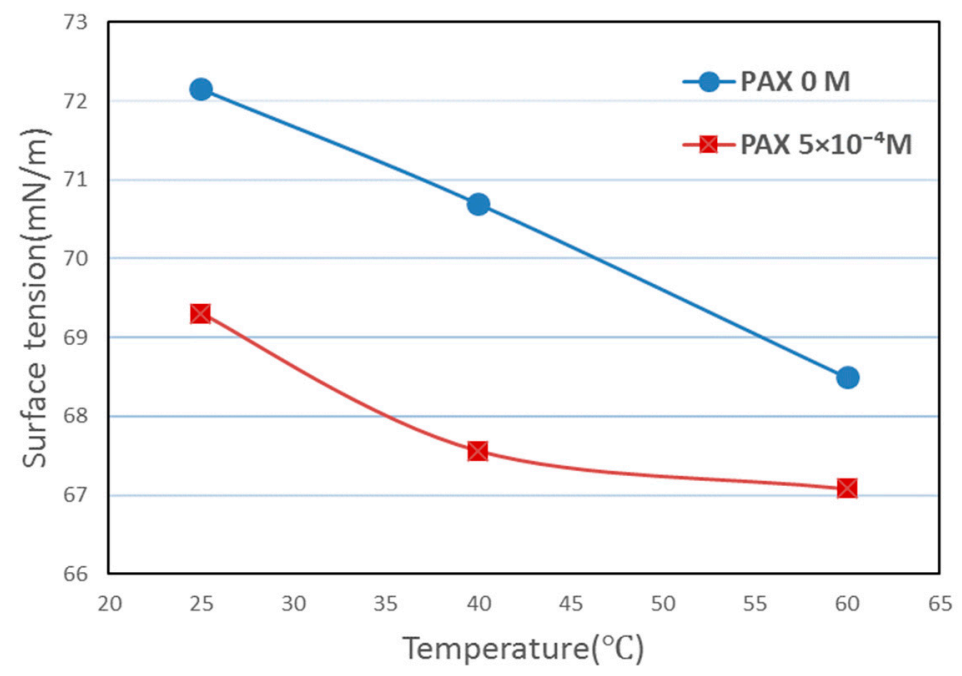

Figure 7. Surface tension of water and PAX solutions at different temperatures.

\section{Discussion}

\subsection{Temperature Effects on Hydrophobicity of Chalcopyrite Surface}

Figure 1 shows that the contact angle bare chalcopyrite surface was $55^{\circ}$. Due to the different experimental methods and mineral resources, as shown by Table 3, the reported water contact angle of bare chalcopyrite surface differed. For example, Pyke et al. [16] set up the relationship between experimental advancing water contact angle and the Time of Flight Secondary Ion Mass Spectrometry (ToF-SIMS) dithiophosphate (DTP)/ $\mathrm{SO}_{3}{ }^{2-}$ index obtained for chalcopyrite particles. The contact angle value of bare surface was $40^{\circ}$. Sharma and Rao [17] studied the adhesion of Paenibacillus polymyxa on chalcopyrite by means of sessile drop contact angle measurement. The water contact angle of the bare surface was $70^{\circ}$ before addition of bacteria and chemicals. In a separation technique of tennantite from chalcopyrite developed by Himawan et al. [18], the water contact angle of fresh polished chalcopyrite surface was as high as $72^{\circ}$. Based on these findings from other researchers, even though the reported contact angle values varied in a large range, most of the records were within $40^{\circ} \sim 78^{\circ}$, by which the value reported in this study was well confirmed. It was also true that high purity chalcopyrite was naturally hydrophobic [19] and the main reason for its mild hydrophobicity is due to the mixed contribution from both the hydrophobic S-S covalent bonds and hydrophilic $\mathrm{Cu}-\mathrm{S}$ and $\mathrm{Fe}-\mathrm{S}$ bonds in the crystal structure of chalcopyrite.

Table 3. Water contact angle on chalcopyrite surface reported by literature.

\begin{tabular}{cccc}
\hline Author & Treatment & Value $\left(^{\circ}\right)$ & Methods \\
\hline Pyke et al. [16] & Bare surface & 40 & N/A \\
Sharma and Rao [17] & Bare surface & 70 & Sessile drop \\
Chen et al. [20] & Bare surface & 72 & Sessile drop \\
Himawan et al. [18] & Bare surface & 72 & Sessile drop \\
Gu et al. [21] & Bare surface & 78 & Sessile drop \\
Rao and Patel [22] & Dixanthogen & $55-100$ & Captive bubble \\
Guo and Yen [23] & PAX 7 $\times 10^{-4} \mathrm{M}$ & $20-80$ & Bubble attachment \\
Muganda et al. [24] & PAX $1 \times 10^{-4} \mathrm{M}$ & $26-55$ & Washburn \\
\hline
\end{tabular}

The microflotation results of chalcopyrite in water (PAX $0 \mathrm{M}$ ) matched well with the contact angle results above. Even without any addition of PAX as collectors, the microflotation recovery of pure chalcopyrite can be as high as $80 \%$. The microflotation results without collectors had the same trend 
with contact angle results of the chalcopyrite bare surface at different temperatures. The hydrophobicity was not significantly altered by elevated temperatures. It was believed that $5 \times 10^{-5} \mathrm{M}$ PAX solution was sufficient enough to obtain a good flotation recovery for high purity particles, which already had a high recovery of $80 \%$ without any xanthate collectors. The natural floatability of chalcopyrite was thus confirmed.

Figure 1 also shows that high contact angle value was obtained with $5 \times 10^{-5} \mathrm{M}$ PAX solution on chalcopyrite surface. Further increasing PAX concentration had little impact on the final results. It was also found that contact angles increased slightly with increasing soaking time. Thus, a longer contacting time with PAX solution was beneficial for enhancing the hydrophobicity of the chalcopyrite surface, although the degree of impact on hydrophobicity was not linearly proportional to the time consumed.

Figure 2 shows that contact angle of chalcopyrite surface soaked in PAX $0 \mathrm{M}$ and PAX $5 \times 10^{-5} \mathrm{M}$ were independent of the change in temperature. When the chalcopyrite surface contacted with xanthate solutions, these two series of data indicated that there was a negligible temperature effect on chalcopyrite surface hydrophobicity at low concentration of PAX solution. At PAX solution concentration above $1 \times 10^{-4} \mathrm{M}$, high temperature is beneficial in enhancing the surface hydrophobicity of chalcopyrite. The rise of contact angle value with temperature was noticeable and the amplitude of increase was proportional to the variation in temperatures. The difference in hydrophobicity became pronounced at a relative higher PAX concentration, and for PAX solutions of different concentrations, the difference in contact angle values became larger at high temperatures.

\subsection{Infrared Study of Xanthate Adsorption on Chalcopyrite Surface}

Infrared spectra have been applied for decades in studying chemical adsorption on mineral surfaces [1,25-29]. Many different infrared techniques such as the KBr pellet method, ATR, diffuse reflectance FTIR and so on have been used for special research purposes. ATR has an easier and more straightforward sample preparation process compared with the KBr pellet method, and the spectra collected does not need further background subtraction. These advantages ensure the accuracy of spectra with little noise.

Figures 3 and 4 showed the spectra of adsorption species of on chalcopyrite surface, which included two major peaks, i.e., the peaks at around $1260 \mathrm{~cm}^{-1}$ due to the $S-S$ bond and the peaks at $1020 \mathrm{~cm}^{-1}$ due to the $C=S$ bond stretching mode [30]. These results suggested that the spectra discussed above were attributed to diamyl dixanthogen as studied by other researchers. For example, Fuerstenau et al. [25] identified that the spectra of diamyl dixanthogen was characterized by peaks at $1021 \mathrm{~cm}^{-1}$ and $1258 \mathrm{~cm}^{-1}$; Allison et al. [26] provided a full list of data illustrating reactions between xanthate and sulfide minerals. The characteristic peaks of diamyl dixanthogen were confirmed at $1260 \mathrm{~cm}^{-1}$ and $1020 \mathrm{~cm}^{-1}$. Cases et al. [31] also proved that $1025 \mathrm{~cm}^{-1}$ and $1259-1261 \mathrm{~cm}^{-1}$ were where the peaks of amyl dixanthogen existed.

It was widely accepted that there were two possible products, i.e., dixanthogen and cuprous xanthate, on copper sulfides when the surface contacted with xanthate. As shown by Table 4, the characteristic peaks of cuprous xanthate ranged from $1190 \mathrm{~cm}^{-1}$ to $1200 \mathrm{~cm}^{-1}$, while the characteristic peaks of dixanthogen varied from $1240 \mathrm{~cm}^{-1}$ to $1270 \mathrm{~cm}^{-1}$, and also $1020 \mathrm{~cm}^{-1}$ to $1040 \mathrm{~cm}^{-1}$, mostly depending on the chain length of xanthate used. In the case of amyl xanthate, Allison et al. [26] found that dixanthogen was the only product on chalcopyrite surface. It was further suggested that the final adsorption products were highly associated with the semiconductor type of sulfide minerals. It was concluded that dixanthogen was usually formed on n-type minerals; metal xanthate was observed on p-type minerals. Chalcopyrite was classified as an n-type mineral and confirmed by other literature [32]. 
Table 4. IR results of xanthate adsorption product on sulfides surface in literature.

\begin{tabular}{ccc}
\hline Author & Results & Method \\
\hline Poling [1] & $\begin{array}{c}\text { CuEX } 1196 \mathrm{~cm}^{-1} \\
(\mathrm{EX})_{2} 1263 \text { and } 1238 \mathrm{~cm}^{-1}\end{array}$ & KBr pellet \\
\hline Fuerstenau et al. [25] & $(\mathrm{AX})_{2} 1021$ and $1258 \mathrm{~cm}^{-1}$ & KBr pellet \\
\hline Allison et al. [26] & $\begin{array}{c}\text { CuAX } 1260 \text { and } 1030 \mathrm{~cm}^{-1} \\
(\mathrm{AX})_{2} 1260 \text { and } 1020 \mathrm{~cm}^{-1}\end{array}$ & KBr pellet \\
\hline Leppinen et al. [27] & $\mathrm{CuEX} 1192 \mathrm{~cm}^{-1}$ & ATR \\
\hline Cases et al. [31] & $(\mathrm{EX})_{2} 1260$ and $1240 \mathrm{~cm}^{-1}$ & Diffuse reflectance FT-IR \\
\hline Persson et al. [33] & $(\mathrm{AX})_{2}, 1025,1260 \mathrm{~cm}^{-1}$ & Diffuse reflectance FT-IR \\
\hline Mielczarski et al. [28] & $(\mathrm{EX})_{2} 1242,1260 \mathrm{~cm}^{-1}$ & Reflectance spectra \\
& $\mathrm{CuAX} 1200,1034 \mathrm{~cm}^{-1}$ & Polarized beam \\
\hline Bulut and Atak [34] & $(\mathrm{AX})_{2} 1270$ and $1035 \mathrm{~cm}^{-1}$ & KBr pellet \\
\hline Mustafa et al. [12] & $(\mathrm{EX})_{2} 1032$ and $1271 \mathrm{~cm}^{-1}$ & KBr pellet \\
\hline
\end{tabular}

Note: $\mathrm{CuEX}=$ cuprous xanthate; $(\mathrm{EX})_{2}=$ ethyl dixanthogen; $(\mathrm{AX})_{2}=$ amyl dixanthogen.

Although it was also reported that both dixanthogen and cuprous xanthate coexisted on the chalcopyrite surface, with amyl dixanthogen being the major product and cuprous xanthate complex forming monolayer [12,28], the spectra in this study showed that only dixanthogen was detected on the chalcopyrite surface and the observation was not affected by changing temperature and xanthate concentration. The difference can be attributed to the different sample preparation methods as applied in different studies. For example, the pure chalcopyrite plate sample was used in the present FTIR-ATR investigation and only the freshly polished surface was studied, through which a noticeable surface oxidation was not an issue. However, when a ground chalcopyrite sample was used for an in-situ FTIR study, the chalcopyrite surface was inevitable oxidized with a wide band $\left(\sim 1000 \mathrm{~cm}^{-1}\right)$ shown on spectra as mentioned by the authors [28]. In addition, in one reported study [12], impure -200 mesh ore sample $(0.8 \% \mathrm{Cu})$ instead of pure mineral sample was used. The fine impure chalcopyrite particles were likely oxidized after grinding and further released copper ions into solution when they contacted water, which should facilitate the formation of a cuprous metal complex on the mineral surface. It is worth noting that the reported infrared (IR) spectra for chalcopyrite particles after grinding showed strong peak at $985.6 \mathrm{~cm}^{-1}$ [12] and the value was close to $1000 \mathrm{~cm}^{-1}$, the observation of which was not applicable for the present study. As such, it was concluded that the only detectable surface adsorption species was amyl dixanthogen with no cuprous xanthate being successfully detected under the test conditions as applied in present study.

Figure 3 indicates that on the chalcopyrite surface, the amount of the adsorption product, i.e., amyl dixanthogen increased with increasing the concentration of PAX solutions. Figure 4 shows that there was no obvious difference in the absorbance among the three spectra collected at the same PAX concentration but different temperatures. The infrared study showed a substantial concentration effect of xanthate adsorption on the chalcopyrite surface. However, the elevated temperature did not impact the amount of dixanthogen on the chalcopyrite surface to a noticeable level as a high concentration of PAX solution did. On the other hand, the elevated temperature had no negative impact on the xanthate adsorption on the chalcopyrite surface, because the absorbance did not decrease at high temperatures. It was also interesting to note that there was no sign of new peaks and obvious shift being observed on these spectra, suggesting that the adsorbed species on the chalcopyrite surface chemically remained the same during the measurements without being influenced by the changes in temperature and collector's concentrations. 


\subsection{Temperature Effect on Resolution Copper Ore Flotation Tests}

Lab flotation test results showed that, when temperature increased from room temperature to $65^{\circ} \mathrm{C}$, the copper recovery of Resolution Copper ore increased, with the grade of copper and byproducts remaining almost the same. As reviewed in the introduction, temperature could impact flotation performance in many aspects, some of which were beyond the scope of the present work, which was focused on the temperature effect on the collector's performance such as increasing the hydrophobicity of chalcopyrite surface during flotation.

Present test results showed that increasing temperature increased the hydrophobicity of chalcopyrite and the finding could be explained in terms of the change in the morphology of dixanthogen on the chalcopyrite surface. As shown by Figure 5A, the adsorbed dixanthogen on chalcopyrite surface were in the form of round patches with defined boundaries at room temperatures. Due to the low melting point of dixanthogen, the surface adsorption species became soft and started "melting" when temperature was above $30^{\circ} \mathrm{C}$. As the temperature reached $45^{\circ} \mathrm{C}$, the long strips as shown by Figure 5C indicated that dixanthogen patches could not keep their original shape. In such case the AFM image scanned at $45^{\circ} \mathrm{C}$ was the result of surface species being scratched by AFM probe instead of the actual shape of dixanthogen with no disturbance. It can be inferred that the "melted" dixanthogen at an elevated temperature had an irregular shape and, therefore, a larger coverage on chalcopyrite surface compared with the patches-like dixanthogen at room temperature.

Based on Cassie's Law [35]:

$$
\cos \theta_{c}=f_{1} \cos \theta_{1}+f_{2} \cos \theta_{2}
$$

where $\theta_{1}$ was the contact angle for component 1 with surface area fraction $f_{1}$, and $\theta_{2}$ was the contact angle for component 2 with surface area fraction $f_{2}$ in the composite material. The melted dixanthogen will have a higher area fraction than patch-like dixanthogen at room temperature, given that the total adsorption amount was the same, as shown by the reported FTIR results. Because dixanthogen, an oily substance mostly responsible for the increase in hydrophobicity during chalcopyrite flotation, had a higher hydrophobicity than the bare chalcopyrite surface, increasing the surface area fraction of dixanthogen at an elevated temperature would result in a larger $\theta c$, i.e., a higher hydrophobicity, of chalcopyrite surface.

Mustafa et al. [12] calculated the isosteric heat of adsorption at different $\mathrm{pH}$ and concentrations and claimed that the adsorption of xanthate onto chalcopyrite surface was an endothermic process, during which the dissolution rate of $\mathrm{Cu}$ ions played an important role in the adsorption process [36]. Taking the enhanced dissolution of chalcopyrite at elevated temperature into account [37], it was thus naturally concluded that the xanthate adsorption process was enhanced by elevated temperatures; although the enhancement was not pronounced enough to be observed from the infrared spectra. It was also worth mentioning that, as shown by Figure 7, increasing temperature also decreased the surface tension of water a little, which was beneficial for frothing during flotation. Such an investigation of the temperature effect on frothing, which was beyond the scope of the present study, was recommended for a future work.

\section{Conclusions}

The present study has been focused on the temperature effect on the collector's performance during chalcopyrite flotation. Contact angle measurement results show that increasing temperature can help increase the hydrophobicity of chalcopyrite when the collector's concentration is fixed, and the reason is attributed to the increased surface area fraction of dixanthogen on the mineral surface at an elevated temperature. FTIR tests results show that dixanthogen is the main adsorption species on the chalcopyrite surface with no cuprous xanthate being detected. The fact that an increased relative intensity of the characteristic peaks is observed on spectra at a high xanthate concentration suggests that increasing xanthate's concentration will increase the adsorption on the chalcopyrite surface. In 
addition, increasing temperature does no harm to the xanthate's adsorption on chalcopyrite because of the similar relative intensity of the characteristic peaks being observed on spectra at the same xanthate concentration. AFM image analysis shows that the morphology of dixanthogen on the chalcopyrite surface changes at an elevated temperature, and the softening and spreading of dixanthogen are regarded as key factors for the increase in the surface hydrophobicity and flotation performance. The enhancement of xanthate adsorption at an elevated temperature due to its endothermic process in nature could also play a role in spite of the fact that no evident increase in the relative intensity of the characteristic peaks is observed on the FTIR spectra.

In summary, the present multi-scale study shows that an increase in temperature from $25^{\circ} \mathrm{C}$ to $65{ }^{\circ} \mathrm{C}$ can increase the collector's performance by increasing hydrophobicity and flotation recovery of chalcopyrite. An increased metal recovery can be achieved with the Resolution Copper ore at the same grade of concentrates. Therefore, it was not necessary to reduce temperature by cooling down the ore before flotation.

Author Contributions: Conceptualization, J.Z.; methodology, J.Z.; software, D.A. and J.Z.; validation, D.A. and J.Z.; formal analysis, J.Z. and D.A.; investigation, J.Z. and D.A.; resources, J.Z.; data curation, D.A. and J.Z.; writing—original draft preparation, D.A.; writing—review and editing, J.Z.; visualization, D.A. and J.Z.; supervision, J.Z.; project administration, J.Z.; funding acquisition, J.Z. All authors have read and agreed to the published version of the manuscript.

Funding: This research was funded by Science Foundation of Arizona, Grant No. SRG0330-08.

Acknowledgments: The support from Resolution Copper is greatly appreciated.

Conflicts of Interest: The authors declare no conflict of interest.

\section{References}

1. Poling, G.W. Infrared Studies of Adsorbed Xanthates. Ph.D. Thesis, University of Alberta, Edmonton, AB, Canada, 1963.

2. Guo, H.; Yen, W.T. Surface potential and dixanthogen stability on chalcopyrite surface. Int. J. Miner. Process. 2005, 76, 205-213. [CrossRef]

3. Leppinen, J.O. FT-IR and flotation investigation of the adsorption of ethyl xanthate on activated and non-activated sulfide minerals. Int. J. Miner. Process. 1990, 30, 245-263. [CrossRef]

4. Kartio, I.; Laajalehto, K.; Kaurila, T.; Suoninen, E. A study of galena (PbS) surfaces under controlled potential in $\mathrm{pH} 4.6$ solution by synchrotron radiation excited photoelectron spectroscopy. Appl. Surf. Sci. 1996, 93, 167-177. [CrossRef]

5. Zhang, J.; Zhang, W. An AFM study of chalcopyrite surface in aqueous solution. In Proceedings of the SME Annual Meeting, Phoenix, AZ, USA, 28 February-3 March 2010.

6. Zhang, J.; Zhang, W. The adsorption of collectors on chalcopyrite surface studied by an AFM. In Proceedings of the Symposium, SME, Denver, CO, USA, 28 February-2 March 2011.

7. Zhang, J.; Zhang, W. An AFM study of collectors' adsorption on minerals in copper/molybdenum flotation. In Proceedings of the SME Annual Meeting, Seattle, WA, USA, 19-22 February 2012.

8. Zhang, J.; Wiyono, S.; Lee, P.; Xiao, W. Surface characterization of xanthate adsorption on molybdenite. In Proceedings of the SME Annual Meeting, Denver, CO, USA, 22-25 February 2009.

9. Vázquez-Sánchez, E.E.; Robledo-Cabrera, A.; Tong, X.; López-Valdivieso, A. Raman spectroscopy characterization of some $\mathrm{Cu}, \mathrm{Fe}$ and $\mathrm{Zn}$ sulfides and their relevant surface chemical species for flotation. Physicochem. Probl. Miner. Process. 2020, 56, 483-492.

10. Lin, I.J. The effect of seasonal variation in temperature on the performance of mineral processing plants. Miner. Eng. 1989, 2, 47-54. [CrossRef]

11. O'Connor, C.T.; Mills, P.J.T. The effect of temperature on the pulp and froth phases in the flotation of pyrite. Miner. Eng. 1990, 3, 615-624.

12. Mustafa, S.; Hamid, A.; Naeem, A. Temperature effect on xanthate sorption by chalcopyrite. J. Colloid. Interf. Sci. 2004, 275, 368-375. [CrossRef] 
13. Strong, A.; Yan, D.; Dunne, R. The detection of xanthate in solution and on sulfide surfaces to help understand and improve mineral separation on industrial plants. In Proceedings of the Centenary of Flotation Symposium, Brisbane, QLD, Australia, 6-9 June 2005.

14. Rao, S.R. Xanthate and Related Compounds; Dekker: New York, NY, USA, 1971.

15. Buckley, A.N.; Hope, G.A.; Woods, R. Metals from sulfide minerals: The role of adsorption of organic reagent in processing technologies. In Solid_Liquid Interfaces; Springer: Berlin/Heidelberg, Germany, 2003; pp. 63-98.

16. Pyke, B.L.; Fornasiero, D.; Grano, S.R.; Ralston, J. Prediction of the flotation rate of chalcopyrite particles in a copper ore. In Proceedings of the Interactions in Mineral Processing, the Fourth UBC-McGill International Symposium on Fundamentals of Mineral Processing, Toronto, ON, Canada, 26-29 August 2001; pp. 47-58.

17. Sharma, P.K.; Rao, K.H. Adhesion of paenibacillus polymyxa on chalcopyrite and pyrite: Surface thermodynamics and extended DLVO theory. Colloid. Surface. B. 2003, 29, 21-38. [CrossRef]

18. Himawan, T.; Hirajima, T.; Sasaki, K.; Okamoto, H. Alternative techniques to separate tennantite from chalcopyrite: Single minerals and arseno copper ore flotation study. In Proceedings of the 26th International Mineral Processing Congress, Innovative Processing for Sustainable Growth-Conference Proceedings, New Delhi, India, 24-28 September 2012; pp. 2038-2051.

19. Heyes, G.W.; Trahar, W.J. The natural floatability of chalcopyrite. Int. J. Miner. Process. 1977, 4, 317-344. [CrossRef]

20. Chen, M.L.; Zhang, L.; Gu, G.H.; Hu, Y.H.; Su, L.J. Effects of microorganisms on surface properties of chalcopyrite and bioleaching. Trans. Nonferrous Met. Soc. China 2008, 18, 1421-1426. [CrossRef]

21. Gu, G.H.; Hu, K.T.; Li, S.K. Surface Characterization of chalcopyrite interacting with leptospirillum ferriphilum. Trans. Nonferrous Met. Soc. China 2014, 24, 1898-1904. [CrossRef]

22. Rao, S.R.; Patel, C.C. Flotation of chalcopyrite by xanthates and dixanthogens under oxidizing conditions. Trans. Am. Inst. Min. Met. Eng. 1963, 226, 243-247.

23. Guo, H.; Yen, W.T. Pulp potential and floatability of chalcopyrite. Miner. Eng. 2003, 16, 247-256. [CrossRef]

24. Muganda, S.; Zanin, M.; Grano, S.R. Influence of particle size and contact angle on the flotation of chalcopyrite in a laboratory batch flotation cell. Int. J. Miner. Process. 2011, 98, 150-162. [CrossRef]

25. Fuerstenau, M.C.; Gutierrez, G.; Elgillani, D.A. The influence of sodium silicate in non-metallic flotation systems. Trans. Met. Soc. Aime. 1968, 241, 319-323.

26. Allison, S.A.; Goold, L.A.; Nicol, M.J.; Granville, A. A determination of the products of reaction between various sulfide minerals and aqueous xanthate solution, and a correlation of the products with electrode rest potentials. Met. Trans. 1972, 3, 2613-2618. [CrossRef]

27. Leppinen, J.O.; Basilio, C.I.; Yoon, R.H. In-situ FT-IR study of ethyl xanthate adsorption on sulfide minerals under conditions of controlled potential. Int. J. Miner. Process. 1989, 26, 259-274. [CrossRef]

28. Mielczarski, J.A.; Cases, J.M.; Mielczarski, E.; Alnot, M.; Ehrhardt, J.J.; Franco, A. Surface products of water and xanthate interaction with copper sulfide minerals. In Proceedings of the Selective Separation, Proceedings of the XIXth International Minerals Processing Congress, San Francisco, CA, USA, 22-27 October 1995; pp. 29-34.

29. Fornasiero, D.; Ralston, J. Cu (II) and Ni (II) activation in the flotation of quartz, lizardite and chlorite. Int. J. Miner. Process. 2005, 76, 75-81. [CrossRef]

30. Chandra, A.P.; Puskar, L.; Simpson, D.J.; Gerson, A.R. Copper and xanthate adsorption onto pyrite surfaces: Implications for mineral separation through flotation. Int. J. Miner. Process. 2012, 114-117, 16-26. [CrossRef]

31. Cases, J.M.; De Donato, P.; Kongolo, M.; Michot, L.J. Interaction between finely ground pyrite with potassium amyl xanthate in flotation: Influence of ph, grinding media and collector concentration. In Proceedings of the XVIII International Mineral Processing Congress, Sydney, Australia, 25-27 May 1994; pp. 663-668.

32. Shuey, R.T. Semiconducting Ore Minerals; Elsevier: Amsterdam, The Netherlands, 1975.

33. Persson, I.; Persson, P.; Valli, M.; Fözö, S.; Malmensten, B. Reactions on sulfide mineral surfaces in connection with xanthate flotation studied by diffuse reflectance FT-IR spectroscopy, atomic absorption spectrophotometry and calorimetry. Int. J. Miner. Process. 1991, 33, 67-81. [CrossRef]

34. Bulut, G.; Atak, S. Role of dixanthogen on pyrite flotation: Solubility, adsorption studies and Eh, FT-IR measurements. Miner. Metall. Proc. 2002, 19, 81-86. [CrossRef]

35. Cassie, A.B.D.; Baxter, S. Wettability of porous surfaces. T. Faraday. Soc. 1944, 40, 546-551. [CrossRef] 
36. Ackerman, P.K.; Harris, G.H.; Klimpel, R.R.; Aplan, F.F. Evaluation of flotation collectors for copper sulfides and pyrite, I. Common sulfhydryl collectors. Int. J. Miner. Process. 1987, 21, 105-127. [CrossRef]

37. King, E.G.; Mah, A.D.; Pankratz, L.B. Thermodynamic properties of copper and its inorganic compounds. In National Standard Reference Data System; NIST: Gaithersburg, MD, USA, 1973.

(C) 2020 by the authors. Licensee MDPI, Basel, Switzerland. This article is an open access article distributed under the terms and conditions of the Creative Commons Attribution (CC BY) license (http://creativecommons.org/licenses/by/4.0/). 